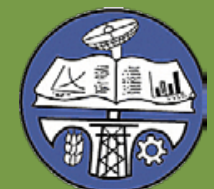

Ethiopian Development Research Institute (EDRI)

\title{
Identifying Priority Value-chains in Ethiopia
}

Rui Benfica and James Thurlow 


\section{TABLE OF CONTENTS}

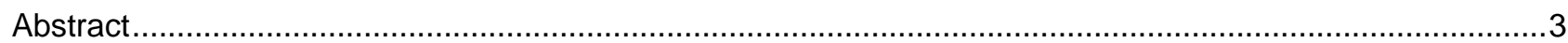

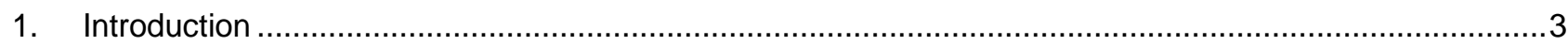

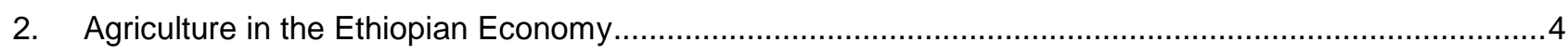

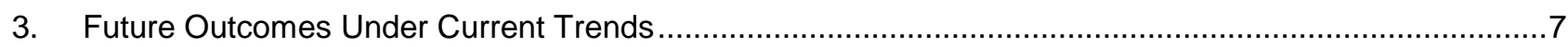

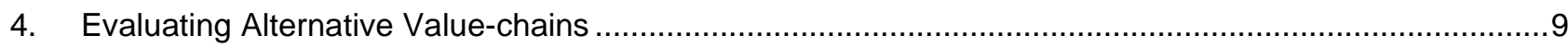

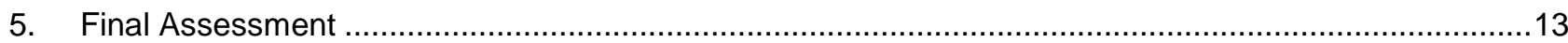

\section{LIST OF TABLES}

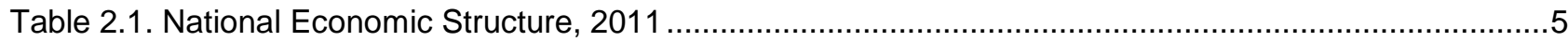

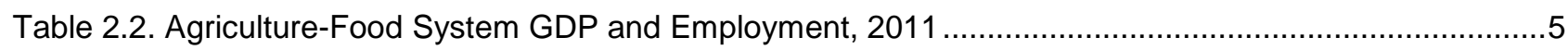

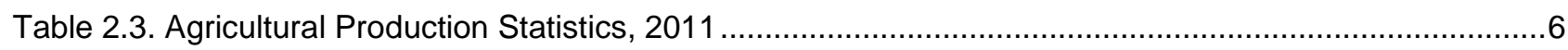

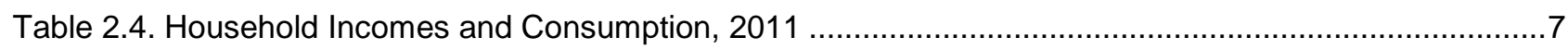

Table 3.1. Baseline "Business-As-Usual" Scenario Results, 2016-2020 .........................................

Table 4.1. Poverty-Growth Elasticity (PGE) Results, 2016-2020 ....................................................10

Table 4.2. Dietary-Diversity-Growth Elasticity (DDGE) Results, 2016-2020 ..........................................11

Table 4.3. Economywide Growth and Employment Linkages, 2016-2020........................................12

Table 5.1. Final Rankings of Value-chains Under Different Weighting Schemes .......................................13

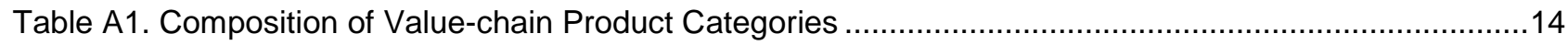

\section{LIST OF FIGURES}

Figure 5.1. Value-chains with Strong Poverty, Nutrition, and Growth Effects 


\section{ABSTRACT}

A major challenge when designing a National Agricultural Investment Plan (NAIP) is deciding how to prioritize between different opportunities, e.g., which value-chains should be promoted over others? Government analysts and policymakers are increasingly asked to adopt a systems approach to planning. This means having to consider sector-wide trade-offs between investment and policy options, e.g., the promotion of one value-chain may come at the expense of another and, so, it is the overall effect that is relevant for policy design. At the same time, policymakers, especially in agrarian economies like Ethiopia's, are asked to quantify how a NAIP not only benefits the agricultural sector, but also contributes to economywide development objectives.

This paper uses an economy-wide model to identify agricultural activities and value-chains in Ethiopia whose expansion would be most effective at generating economic growth, reducing national and rural poverty, creating jobs, and diversifying diets. Results indicate that expanding cereals production would continue to contribute positively to national pro-poor growth. However, the analysis suggests that there is no single value-chain that can achieve all policy objectives. Instead, a more balanced portfolio of valuechains would not only enhance agriculture's future contribution to poverty reduction and economic growth, but also promote faster rural transformation and dietary diversification, both of which are needed to create job opportunities and improve nutrition outcomes over the longer-term. After considering alternative weighting schemes for competing policy goals, the final analysis suggests that vegetables and fruits/tree crops should be considered "priority" value-chains, because these are among the most effective at achieving multiple policy objectives. Other highly-ranked value-chains include oilseeds, tobacco/cotton/tea, and milk/dairy.

Keywords: value-chains; economic growth; poverty; employment; diet diversity; Ethiopia

\section{INTRODUCTION}

Government analysts and policymakers are increasingly asked to adopt a systems approach to planning. This means having to consider sector-wide trade-offs between investment and policy options, e.g., the promotion of one value-chain may come at the expense of another and so it is the overall effect that is relevant for policy design. At the same time, policymakers, especially in agrarian economies like Ethiopia's, are asked to quantify how a NAIP not only benefits the agricultural sector, but also contributes to economywide development objectives. This paper uses an economy-wide model to identify agricultural activities and value-chains in Ethiopia whose expansion would be most effective at generating economic growth, reducing national and rural poverty, creating jobs, and diversifying diets.

The Rural Investment and Policy Analysis (RIAPA) model is used to estimate how increasing production in Ethiopia's different agricultural sectors leads to changes in national and household outcomes. ${ }^{1}$ The RIAPA model and the analytical approach presented in this paper were developed by the International Fund for Agricultural Development (IFAD) and the International Food Policy Research Institute (IFPRI). One of RIAPA's main features is that it captures economic linkages between sectors and rural-urban economies, as well as changes throughout the agriculture-food system (AFS). The paper is structured as follows: Section 2 situates agriculture within the national economy; Section 3 establishes baseline expectations until 2020; Section 4

\footnotetext{
${ }^{1}$ The development of the RIAPA model and this Ethiopian study were both funded by IFAD, IFPRI, the CGIAR Research Program on "Policies, Markets and Institutions" (PIM), and the Gates Foundation project "Advancing Research on Nutrition and Agriculture" (ARENA).
} 
evaluates the impacts of promoting alternative value-chains; and Section 5 concludes by providing a final assessment of priority value-chains in Ethiopia.

\section{AGRICULTURE IN THE ETHIOPIAN ECONOMY}

Agriculture forms only part of Ethiopia's economy, and farming is only one source of income for rural households. RIAPA is an economy-wide model and its core database is a social accounting matrix (SAM) that captures all income and expenditure flows between all economic actors in the country, including producers, consumers, government, and the rest of the world (see Box 1). Ethiopia's model uses a 2011 SAM and the 2010/11 Household Consumption and Expenditure Survey to separate the whole economy into 70 sectors and 13 factors of production. ${ }^{2}$ Table 2.1 describes RIAPA's base-year production and trade structure.

Agriculture generates 43 percent of national GDP, 76 percent of total employment, and 48 percent of total export earnings. Crops dominate the agricultural sector, although livestock is also an important source of GDP and employment. Part of agricultural output is supplied to downstream agro-processing, but this generates only 2 percent of GDP, 1 percent of employment, and 2 percent of exports. This is because most cereals in Ethiopia are grown, prepared and consumed within households, and because coffee, which generates two-thirds of total export earnings, is exported unprocessed. Ethiopia imports most nonagricultural manufactured goods, such as petroleum, machinery and vehicles. Almost half of national GDP is generated by services, which are dominated by trade and business services.

\section{Box 1. The Rural Investment and Policy Analysis (RIAPA) model}

RIAPA is a computable general equilibrium (CGE) model that simulates the functioning of a market economy, including markets for products and factors, i.e., land, labor, and capital. RIAPA measures how impacts are mediated through prices and resource reallocations, and ensures that resource and macroeconomic constraints are respected, such as when inputs or foreign exchange are limited. RIAPA provides a consistent "simulation laboratory" for quantitatively examining value-chain interactions and spillovers at national, sub-national, and household levels.

RIAPA divides the economy into sectors and household groups that act as individual economic agents. Producers maximize profits and supply output to national markets, where it may be exported or combined with imports depending on relative prices, with foreign prices affected by exchange rate movements. Producers combine factors and intermediate inputs using sector-specific technologies. Maize farmers, for example, use a unique combination of land, labor, machinery, fertilizer, and purchased seeds. Workers are divided by education levels, and agricultural capital is separated into crop and livestock categories. Labor and capital are in fixed supply, but less-educated workers are treated as underemployed. Producers and households pay taxes to the government, who uses these and other revenues to finance public services and social transfers. Remaining revenues are added to private savings and foreign capital inflows to finance investment, i.e., investment is driven by levels of savings. RIAPA is dynamic, with past investment determining current capital availability.

RIAPA tracks changes in incomes and expenditures for different household groups, including changes in food and non-food consumption. Poverty impacts are measured using survey-based microsimulation analysis. Individual survey households map to the model's household groups. Estimated consumption changes in the model are applied proportionally to survey households, and post-simulation consumption values are recalculated and compared to a poverty line to determine households' poverty status.

\footnotetext{
${ }^{2}$ RIAPA's SAMs follow standard "Nexus Project" data definitions and estimation procedures. The Nexus Project is a collaboration between IFAD, IFPRI, other international organizations, and national research and statistical agencies. Ethiopia's 2011 SAM was built by IFPRI and the Ethiopian Policy Analysis Unit (EPAU).
} 
Table 2.1. National Economic Structure of Ethiopia, 2011

\begin{tabular}{|c|c|c|c|c|c|c|}
\hline & \multicolumn{4}{|c|}{ Share of total (\%) } & \multirow[b]{2}{*}{$\begin{array}{l}\text { Exports I } \\
\text { output (\%) }\end{array}$} & \multirow{2}{*}{$\begin{array}{c}\text { Imports } \\
\text { demand } \\
(\%)\end{array}$} \\
\hline & GDP & $\begin{array}{c}\text { Employ- } \\
\text { ment }\end{array}$ & Exports & Imports & & \\
\hline All sectors & 100.0 & 100.0 & 100.0 & 100.0 & 10.9 & 24.6 \\
\hline Agriculture & 42.5 & 76.3 & 47.6 & 2.9 & 16.6 & 3.0 \\
\hline Crops & 30.2 & 52.9 & 43.3 & 2.9 & 24.6 & 4.9 \\
\hline Livestock & 8.9 & 14.3 & 4.4 & 0.0 & 6.5 & 0.1 \\
\hline Forestry & 3.4 & 9.1 & 0.0 & 0.0 & 0.0 & 0.0 \\
\hline Fishing & 0.0 & 0.1 & 0.0 & 0.0 & 0.0 & 0.0 \\
\hline Industry & 11.4 & 4.4 & 7.6 & 72.7 & 3.4 & 47.7 \\
\hline Mining & 1.6 & 0.5 & 2.8 & 0.1 & 16.6 & 1.4 \\
\hline Manufacturing & 3.7 & 2.2 & 4.9 & 68.7 & 5.5 & 64.9 \\
\hline Agro-processing & 2.1 & 1.3 & 2.4 & 7.5 & 4.4 & 26.6 \\
\hline Other manufactures & 1.6 & 1.0 & 3.3 & 62.8 & 9.2 & 79.1 \\
\hline Other industry & 6.1 & 1.7 & 0.0 & 4.0 & 0.0 & 7.1 \\
\hline Services & 46.1 & 19.2 & 44.7 & 24.3 & 11.4 & 12.3 \\
\hline Trade, hotels, catering & 18.5 & 9.2 & 14.1 & 1.4 & 8.6 & 1.8 \\
\hline Transport services & 5.6 & 4.6 & 23.7 & 17.8 & 36.5 & 46.3 \\
\hline Finance $\&$ business & 13.4 & 0.9 & 2.8 & 5.2 & 3.2 & 11.0 \\
\hline Government & 6.5 & 2.5 & 4.1 & 0.0 & 6.9 & 0.0 \\
\hline Other services & 2.0 & 2.1 & 0.0 & 0.0 & 0.0 & 0.0 \\
\hline
\end{tabular}

Source: RIAPA CGE Model and SAM.

Notes: GDP is gross domestic product; employment is workers in primary jobs. The final two columns report the share of exports in total sectoral output and the share of imports in total commodity demand. Agro-processing includes beverages and tobacco, but not wood products; catering services includes restaurants and other meals prepared away from the home; and transport includes communications

Table 2.2. Agriculture-Food System GDP and Employment in Ethiopia, 2011

\begin{tabular}{lrc}
\hline & \multicolumn{2}{c}{ Share of national total (\%) } \\
& GDP & Employment \\
\hline National economy & 100.0 & 100.0 \\
Agriculture-food system & $\mathbf{5 1 . 4}$ & $\mathbf{8 1 . 2}$ \\
Direct production & $\mathbf{4 4 . 3}$ & $\mathbf{7 7 . 1}$ \\
Agriculture & 42.5 & 76.3 \\
Agro-processing & 1.8 & 0.8 \\
Input production & $\mathbf{1 . 3}$ & $\mathbf{0 . 8}$ \\
Agriculture & 0.9 & 0.7 \\
Agro-processing & 0.3 & 0.1 \\
Trade and transport & $\mathbf{5 . 9}$ & $\mathbf{3 . 3}$ \\
Agriculture & 4.9 & 2.7 \\
Agro-processing & 1.0 & 0.6 \\
Hotels and catering & $\mathbf{4 . 0}$ & $\mathbf{2 . 2}$ \\
\hline
\end{tabular}

Source: RIAPA CGE Model and SAM.

Notes: GDP is gross domestic product; employment is workers in primary jobs. Agro-processing includes foods, beverages, tobacco, paper products, and cotton yarn; and catering services includes restaurants and other meals prepared away from the home.

Agriculture's role in the economy extends beyond the sector itself, with many industrial and service sectors forming parts of the AFS. Table 2.2 uses the national SAM to estimate the share of total GDP and employment in Ethiopia's AFS. Agriculture and agro-processing together account for 44 percent and 77 percent of GDP and employment, respectively. These sectors use domestically-produced inputs, such as seed and animal feed, whose production creates additional value-added and jobs within the AFS. An even larger AFS component is moving agriculture-related products between farmers, processors, and markets. 
Households also consume meals prepared outside the home, such as in hotels and restaurants. In total, the AFS accounts for 51 percent and 81 percent of national GDP and employment, respectively. Most of the economy, population and workforce therefore depend on agriculture, either directly or indirectly.

RIAPA is used to evaluate different agricultural value-chains. Table 2.3 provides summary production statistics for the 15 product categories analyzed here, as well as an "other agriculture" category that includes value-chains not analyzed. The latter includes forestry, fishing, and crops like chat and sugarcane. Table A1 in the Appendix lists the detailed products included each category. Cereals are the dominant crops in Ethiopia, together accounting for 34 percent of total agricultural GDP. Although coffee is the country's main export, it accounts for a much smaller share of GDP (only 8 percent). Other major crops include pulses and vegetables. Livestock is a major sub-sector, consisting mainly of cattle, goats, and sheep.

Table 2.3. Agricultural Production Statistics for Ethiopia, 2011

\begin{tabular}{|c|c|c|c|c|c|}
\hline & $\begin{array}{c}\text { Agriculture } \\
\text { GDP share (\%) }\end{array}$ & $\begin{array}{c}\text { GDP per } \\
\text { worker (\$) }\end{array}$ & $\begin{array}{c}\text { Cultivated } \\
\text { hectares ('000s) }\end{array}$ & $\begin{array}{l}\text { Hectares per } \\
\text { worker }\end{array}$ & $\begin{array}{c}\text { Crop yield } \\
\text { (tons/hectare) }\end{array}$ \\
\hline Agriculture & 100.0 & 418 & 15,282 & 1.8 & - \\
\hline Maize & 6.1 & 328 & 2,000 & 1.0 & 3.3 \\
\hline Sorghum/millet & 7.7 & 327 & 2,155 & 1.2 & 2.2 \\
\hline Wheat/barley & 10.2 & 401 & 2,669 & 1.1 & 2.2 \\
\hline Teff & 9.9 & 506 & 3,000 & 0.7 & 1.5 \\
\hline Pulses & 7.1 & 444 & 1,709 & 1.0 & 1.6 \\
\hline Oilseeds & 3.8 & 828 & 843 & 0.6 & 0.9 \\
\hline Root crops & 1.9 & 434 & 163 & 3.0 & 23.3 \\
\hline Vegetables & 6.8 & 338 & 426 & 5.3 & 4.4 \\
\hline Fruits/tree crops & 4.4 & 421 & 849 & 1.4 & 7.0 \\
\hline Coffee & 7.7 & 648 & 520 & 2.6 & 0.5 \\
\hline Tobacco/cotton/tea & 0.6 & 520 & 429 & 0.3 & 0.5 \\
\hline Milk/dairy & 3.4 & 858 & - & - & - \\
\hline Cattle & 7.8 & 366 & - & - & - \\
\hline Poultry & 1.8 & 1,037 & - & - & - \\
\hline Goats/sheep/camels & 8.4 & 450 & - & - & - \\
\hline Other agriculture & 12.4 & 328 & 519 & 8.1 & 6.7 \\
\hline
\end{tabular}

Source: RIAPA CGE Model and SAM.

Notes: Table A1 in Appendix lists the crops or products included in each value-chain category.

Finally, RIAPA contains 15 representative household groups, separated into rural and urban consumption quintiles, with rural households separated into farm and nonfarm groups. Table 2.4 describes aggregate income and consumption patterns. The total population of 76 million people consume, on average, US\$ 322 of goods and services per person each year (at market exchange rates unadjusted for purchasing power parity). Consumption levels are much lower in rural areas and among the poor. Poor households tend to spend more of their earnings on food consumption and a smaller share on processed foods. Starches from cereals and roots dominate the consumption patterns of the rural poor, whereas non-poor and urban households consume more meat, fish, and eggs. Finally, poor rural households are, on average, more reliant on incomes from farming and from less-educated labor, suggesting that agriculture and the rural nonfarm economy play crucial roles in the livelihoods of the poorest population. 
Table 2.4. Household Incomes and Consumption in Ethiopia, 2011

\begin{tabular}{lcrcr}
\hline & National & Rural & Rural poor & Urban \\
\hline Population (millions) & \multicolumn{1}{c}{$\mathbf{7 6 . 1}$} & $\mathbf{6 5 . 2}$ & $\mathbf{2 9 . 3}$ & \multicolumn{1}{c}{$\mathbf{1 0 . 9}$} \\
Consumption per capita (\$/year) & \multicolumn{1}{c}{$\mathbf{3 2 2}$} & $\mathbf{2 6 8}$ & $\mathbf{1 6 9}$ & $\mathbf{6 4 9}$ \\
Food consumption share (\%) & $\mathbf{1 0 0 . 0}$ & $\mathbf{1 0 0 . 0}$ & $\mathbf{1 0 0 . 0}$ & $\mathbf{1 0 0 . 0}$ \\
$\quad$ Cereals and roots & 26.6 & 29.2 & 35.3 & 18.4 \\
Vegetables & 5.9 & 5.8 & 6.6 & 6.2 \\
Fruits & 4.3 & 5.2 & 6.6 & 1.4 \\
Meat, fish and eggs & 21.2 & 17.4 & 9.7 & 33.2 \\
Milk and dairy & 6.0 & 7.0 & 7.8 & 2.9 \\
Pulses and oilseeds & 8.4 & 8.8 & 9.6 & 7.3 \\
Other foods & 27.5 & 26.6 & 24.5 & 30.7 \\
Food consumption share (\%) & 60.2 & 64.4 & 64.2 & 49.7 \\
Processed food share (\%) & 17.3 & 17.5 & 16.4 & 16.8 \\
Total household income (\%) & $\mathbf{1 0 0 . 0}$ & $\mathbf{1 0 0 . 0}$ & $\mathbf{1 0 0 . 0}$ & $\mathbf{1 0 0 . 0}$ \\
Crop land returns & 10.7 & 15.0 & 21.6 & 0.7 \\
Labor remuneration & 36.5 & 41.6 & 54.8 & 24.5 \\
Less-educated workers & 31.2 & 39.2 & 53.4 & 12.1 \\
Better-educated workers & 5.3 & 2.4 & 1.3 & 12.4 \\
Capital profits & 46.5 & 36.1 & 14.1 & 71.3 \\
Other sources & 6.2 & 7.4 & 9.6 & 3.4 \\
\hline
\end{tabular}

Source: RIAPA CGE Model and SAM.

Notes: Food consumption excludes meals prepared outside the household. Processed foods exclude products processed and consumed within the household. Better-educated workers are those who have at least completed primary schooling. Capital income includes gross operating surplus. Other income sources include social and foreign transfers. Table A1 in the Appendix lists the crops or products included in each value-chain category.

\section{FUTURE OUTCOMES UNDER CURRENT TRENDS}

RIAPA first establishes a baseline scenario for the period 2016 to 2020 assuming recent trends continue. Table 3.1 summarizes this "business-as-usual" scenario. Initial values are for 2016, which is the simulated base year for the analysis derived by imposing trends on the model. Population and labor supply grow at about 3 percent per year, and cropland area expands at roughly the same pace as the rural population. Productivity growth is adjusted to replicate trends in the sectoral pattern of GDP. The table's final two columns compare model outcomes to observed trends. Agricultural GDP continues to grow more slowly than industry and services. Overall, national GDP in the model grows at 9 percent per year, which is faster than the population, implying rising GDP per capita. We purposefully simulate slower-than-observed GDP growth given the likelihood that the pace of economic development in Ethiopia will decelerate slightly from its recent stellar performance.

RIAPA measures how the pace and sectoral pattern of GDP growth affects household incomes and consumption levels. This is based on sectors' differing resource demands and households' factor endowments and consumption patterns. Poor households are often more dependent on incomes from lesseducated workers, and so expanding production in sectors that employ these workers more intensively is more likely to benefit the poor. Similarly, expanding production and lowering prices of products that poor households consume can also raise their total consumption and move some households to levels above the poverty line. 
Table 3.1. Baseline "Business-As-Usual" Scenario Results for Ethiopia, 2016-2020

\begin{tabular}{|c|c|c|c|}
\hline & \multirow[b]{2}{*}{$\begin{array}{c}\text { Initial value, } \\
2016\end{array}$} & \multicolumn{2}{|c|}{ Average annual change (\%) } \\
\hline & & $\begin{array}{l}\text { Baseline } \\
\text { scenario }\end{array}$ & $\begin{array}{l}\text { Observed } \\
\text { trends }\end{array}$ \\
\hline Total population (1000s) & 84,403 & 2.7 & 2.7 \\
\hline Rural areas & 71,302 & 2.2 & 2.2 \\
\hline Urban areas & 13,101 & 4.8 & 4.8 \\
\hline Total GDP (\%) & 100.0 & 8.7 & 11.3 \\
\hline Agriculture & 41.4 & 7.4 & 8.2 \\
\hline Industry & 11.7 & 9.6 & 14.4 \\
\hline Agro-processing & 2.3 & 10.9 & $\mathrm{n} / \mathrm{a}$ \\
\hline Services & 46.9 & 9.6 & 12.9 \\
\hline Labor employment (1000s) & 41 & 3.2 & 3.3 \\
\hline Cropland ('000 hectares) & 16,793 & 2.0 & 2.0 \\
\hline Capital stock (index) & 270 & 5.8 & $\mathrm{n} / \mathrm{a}$ \\
\hline Consumption per capita (\$) & 383 & 5.0 & 6.7 \\
\hline Rural households & 327 & 5.6 & $\mathrm{n} / \mathrm{a}$ \\
\hline Urban households & 689 & 2.4 & $\mathrm{n} / \mathrm{a}$ \\
\hline Poverty headcount rate (\%) & 17.7 & -12.9 & -4.5 \\
\hline Rural areas & 17.1 & -14.0 & -4.2 \\
\hline Urban areas & 21.2 & -8.3 & -5.1 \\
\hline Poverty-growth elasticity & - & -2.2 & -0.5 \\
\hline Semi-PGE & - & -0.3 & -0.2 \\
\hline
\end{tabular}

Source: RIAPA CGE Model and SAM.

Notes: Observed population, GDP, and employment trends are for 2004-2014; poverty and PGE is for 2002-2012. Poverty headcount rate is the share of the population with consumption below the official poverty line. PGE is the percentage change in the poverty headcount rate per one percent increase in GDP per capita, whereas the semi-PGE uses the percentage point change in the poverty rate.

Rural households' consumption grows faster than urban households' consumption in the baseline, albeit from a much lower starting point. This reflects faster urban population growth, and is despite faster nonagricultural GDP growth, from which urban households are more likely to benefit. Higher per capita consumption causes the poverty headcount rate to fall. This is the share of the population with consumption levels below the official poverty line. RIAPA's microsimulation analysis estimates that the national poverty rate would fall by 12.9 percent per year in the baseline scenario, with a slightly faster decline in rural areas. Note that this is a percentage, not percentage point, change in the poverty rate. In absolute terms, the poverty rate falls from 29 percent in 2011 to 18 percent and 9 percent in 2016 and 2020, respectively. ${ }^{3}$

The pace of poverty reduction should be assessed in relation to economic growth. Box 2 describes RIAPA's main outcome indicators. The baseline poverty-growth elasticity (PGE) is -2.2 , which means that a one percent increase in per capita GDP causes the poverty headcount rate to decline by 2.2 percent. This is higher than Ethiopia's observed PGE of -0.5 for the period 2002-2012. This discrepancy comes from the PGE being calculated using the initial poverty rate. The large percentage reductions in the poverty rate, and hence the large PGE, is due to the rapid decline in the poverty rate observed during 2002-2012. An alternative measure that is not affected by changes in the initial poverty rate is the semi-PGE, which indicates that a one percent increase in per capita GDP reduces the poverty rate by 0.3 percentage points, which is close to the 0.2 observed semi-PGE. Overall, the baseline captures Ethiopia's recent trends and

${ }^{3}$ RIAPA is calibrated to a 2011 SAM and the poverty module is benchmarked to the $2010 / 11$ household survey. 


\section{Box 2. Outcome Indicators}

Value-chains are compared based on their impacts on economic growth, employment, poverty, and nutrition. These headline outcome indicators are defined below.

Economic growth is measured by real GDP at factor cost, either for all sectors (total GDP) or for the agriculture-food system (AFS GDP) (see Table 2.2).

Employment is paid and unpaid work, including home enterprises. Workers may have multiple jobs, but only their primary job is considered and no adjustment is made for hours worked.

Poverty is measured by the poverty headcount or gap. The former is the share of the population with consumption below the poverty line, and the latter is the cumulative distance between poor people's consumption levels and the poverty line (i.e., depth of poverty).

Dietary diversity score is calculated for household groups using food expenditure shares. Diversity is estimated using a cross entropy measure across six food categories (cereals and roots; vegetables; fruits; meat, fish and eggs; milk and dairy; and pulses and oilseeds) relative to an estimated "ideal" food budget allocation. A more diverse diet is assumed to be associated with improved nutrition outcomes.

Poverty-growth elasticity (PGE) is the percentage change in the poverty rate divided by the per capita GDP growth rate. Semi-PGEs use percentage point changes in the poverty rate.

Dietary-diversity-growth elasticity (DDGE) is the percentage change in the dietary diversity score of poor households divided by the per capita GDP growth rate.

Economywide growth (employment) elasticity is the percentage in either total or AFS GDP (employment) divided by the percentage change in agricultural GDP.

fundamental growth-poverty relationships. The baseline provides a plausible reference scenario for evaluating the further expansion of agricultural value-chains.

\section{EVALUATING ALTERNATIVE VALUE-CHAINS}

RIAPA is used to simulate the effects of expanding farm production within existing agricultural value-chains. Total factor productivity growth in each group of agricultural products is accelerated beyond baseline growth rates, such that, in each value-chain scenario, total agricultural GDP is one percent higher in 2020 than it is in the baseline scenario. ${ }^{4}$ Expanding agricultural production increases supply to downstream processing activities and generates demand for agricultural trade and transport services. Agricultural subsectors differ in size, and, so, to achieve the same absolute increase in total agricultural value-added, it is necessary for smaller value-chains to expand more rapidly than larger ones. Table 2.3 lists the value-chains analyzed in this brief, including their initial GDP shares. Tobacco/cotton/tea is the smallest agricultural subsector on this list (0.6 percent of agricultural GDP), and so these crops need larger productivity gains to match the effects of even modest average cereal yield gains. While such rapid growth may be difficult for these crops to achieve, targeting the same absolute increase in agricultural GDP allows us to compare results across the different value-chain scenarios.

Table 4.1 reports the estimated semi-PGEs for each scenario. Expanding maize production reduces the national poverty headcount rate by 0.48 percentage points for every one percent increase in agricultural

\footnotetext{
${ }^{4}$ The choice to target one percent increase in agricultural GDP is somewhat arbitrary, since results are largely unaffected by the magnitude of the target growth acceleration.
} 
GDP, making maize a "pro-poor" value-chain. However, oilseeds and root crops have the largest PGEs growth in these value-chains is most effective at reducing national poverty. These products also have strong linkages to rural poverty reduction. Note that value-chain PGEs are often larger than the baseline's overall PGE, implying that agricultural growth is more pro-poor than nonagricultural growth. Rural PGEs also tend to be larger than national PGEs, indicating that, as expected, agricultural growth favors the rural poor.

Table 4.1. Poverty-Growth Elasticity (PGE) Results for Ethiopia, 2016-2020

\begin{tabular}{|c|c|c|c|c|c|c|}
\hline \multirow{2}{*}{$\begin{array}{l}\text { Baseline or targeted } \\
\text { sector within } \\
\text { agriculture }\end{array}$} & \multicolumn{6}{|c|}{ Estimated Semi-PGE (sectoral rank in parentheses) } \\
\hline & \multicolumn{2}{|c|}{$\begin{array}{c}\text { National poverty } \\
\text { headcount }\end{array}$} & \multicolumn{2}{|c|}{$\begin{array}{l}\text { Rural poverty } \\
\text { headcount }\end{array}$} & \multicolumn{2}{|c|}{$\begin{array}{c}\text { National } \\
\text { poverty gap }\end{array}$} \\
\hline Baseline & -0.30 & & -0.31 & & -0.09 & \\
\hline Maize & -0.48 & (5) & -0.51 & (5) & -0.12 & (3) \\
\hline Sorghum/millet & -0.45 & (6) & -0.48 & (6) & -0.11 & (5) \\
\hline Wheat/barley & -0.40 & (8) & -0.44 & (7) & -0.10 & (6) \\
\hline Teff & -0.28 & $(11)$ & -0.25 & $(11)$ & -0.08 & (9) \\
\hline Pulses & -0.57 & (3) & -0.60 & (3) & -0.11 & (4) \\
\hline Oilseeds & -2.08 & (1) & -2.87 & (1) & -0.49 & (1) \\
\hline Root crops & -1.08 & $(2)$ & -1.20 & (2) & -0.34 & (2) \\
\hline Vegetables & -0.55 & (4) & -0.52 & (4) & -0.09 & (7) \\
\hline Fruits/tree crops & -0.36 & $(10)$ & -0.38 & (9) & -0.07 & (11) \\
\hline Coffee & -0.37 & $(9)$ & -0.39 & $(8)$ & -0.08 & $(10)$ \\
\hline Tobacco/cotton/tea & -0.42 & (7) & -0.36 & (10) & -0.09 & (8) \\
\hline Milk/dairy & -0.07 & $(12)$ & -0.06 & (13) & 0.05 & $(14)$ \\
\hline Cattle & 0.77 & (15) & 1.01 & (15) & 0.29 & (15) \\
\hline Poultry & -0.04 & (14) & -0.02 & (14) & 0.04 & (13) \\
\hline Goats/sheep/camels & -0.04 & (13) & -0.08 & (12) & 0.01 & $(12)$ \\
\hline
\end{tabular}

Source: RIAPA CGE Model and SAM.

Notes: Semi-PGE is the percentage point change in the poverty rate per one percent increase in GDP per capita driven by GDP growth originating from within the targeted sector. Poverty headcount rate is the share of the national or rural population with consumption levels below the official poverty line. Poverty gap rate is the cumulative distance between poor people's consumption levels and the poverty line.

Sectoral rank in parentheses.

Headcount rates focus on people living just below the poverty line, whereas poverty gaps measure how far poor households are from the poverty line. Poverty gaps therefore better reflect the conditions of the poorest of the poor. These households may have different consumption patterns and asset endowments than the less poor, such as limited access to land, and so we do not expect value-chains to be equally effective at reducing poverty headcounts and gaps. In Table 4.1, for example, cereals are more effective at reducing the poverty gap than the poverty headcount rate (relative to other value-chains), indicating that poorest households benefit more from cereals expansion than do households closer to the poverty line. Nevertheless, the results indicate that oilseeds and root crops have large poverty gap elasticities, indicating that their expansion benefits the poorest population more than do other value-chains.

Table 4.2 reports estimated dietary-diversity-growth elasticities (DDGE), which show how effective valuechains are at diversifying the dietary patterns of household groups. Diversity is measured by food expenditures across six major food groups (see Box 2). Cereals and roots are already the dominant food group (see Table 2.4), so expanding their supply reduces dietary diversity by increasing availability and reducing prices. Coffee and tobacco/cotton/tea do not produce foods, and so expanding their production does not directly affect food availability and diets. Instead, these value-chains affect food access by raising 
incomes, thereby indirectly affecting diets. ${ }^{5}$ Overall, the value-chains that are most effective at promoting dietary diversity among poor rural households are vegetables, fruits, and milk/dairy. Note that fruits include nuts and other tree crops.

Table 4.2. Dietary-Diversity-Growth Elasticity (DDGE) Results for Ethiopia, 2016-2020

\begin{tabular}{lrrrrrr}
\hline & \multicolumn{2}{c}{ Estimated DDGE (sectoral rank in parentheses) } \\
\begin{tabular}{l} 
Targeted sector within \\
\multicolumn{1}{c}{ agriculture }
\end{tabular} & \multicolumn{2}{c}{ All } & \multicolumn{2}{c}{$\begin{array}{c}\text { Rural } \\
\text { households }\end{array}$} & \multicolumn{2}{c}{$\begin{array}{c}\text { Poor rural } \\
\text { households }\end{array}$} \\
\hline Maize & -0.50 & $(8)$ & -0.80 & $(10)$ & -1.40 & $(14)$ \\
Sorghum/millet & -0.54 & $(9)$ & -0.83 & $(12)$ & -1.25 & $(13)$ \\
Wheat/barley & -0.58 & $(11)$ & -0.91 & $(14)$ & -1.23 & $(12)$ \\
Teff & -0.66 & $(12)$ & -0.86 & $(13)$ & -0.92 & $(11)$ \\
Pulses & 0.62 & $(4)$ & 0.82 & $(4)$ & 0.89 & $(4)$ \\
\hline Oilseeds & 0.25 & $(5)$ & 0.20 & $(5)$ & 0.22 & $(5)$ \\
Root crops & -0.57 & $(10)$ & -0.82 & $(11)$ & -1.80 & $(15)$ \\
Vegetables & 1.89 & $(2)$ & 2.47 & $(1)$ & 2.57 & $(1)$ \\
Fruits/tree crops & 2.10 & $(1)$ & 2.37 & $(2)$ & 2.16 & $(2)$ \\
Coffee & -0.02 & $(6)$ & -0.04 & $(7)$ & -0.07 & $(9)$ \\
\hline Tobacco/cotton/tea & -0.04 & $(7)$ & -0.04 & $(6)$ & -0.06 & $(8)$ \\
Milk/dairy & 0.99 & $(3)$ & 1.09 & $(3)$ & 1.29 & $(3)$ \\
Cattle & -2.17 & $(15)$ & -1.88 & $(15)$ & -0.24 & $(10)$ \\
Poultry & -0.80 & $(14)$ & -0.62 & $(9)$ & 0.18 & $(6)$ \\
Goats/sheep/camels & -0.74 & $(13)$ & -0.56 & $(8)$ & 0.08 & $(7)$ \\
\hline
\end{tabular}

Source: RIAPA CGE Model and SAM.

Notes: Dietary diversity score (DDS) measures the unevenness of the real value of consumption across major food groups (i.e., negative entropy distance from an estimated ideal food budget shares). DDGE is the percentage change in the DDS per one percent increase in GDP per capita driven by GDP growth originating within the targeted agricultural sector.

Sectoral rank in parentheses.

Table 4.3 reports the growth and employment effects of expanding agricultural production in different value-chains. Although the scenarios are labeled by the names of the value-chains in which productivity growth originates, it does not imply that all GDP and employment growth occurs only within these valuechains. Increasing maize productivity, for example, may allow farmers to diversify production by reallocating resources to other crops and activities, including nonfarm enterprises. Increasing value-chain workers' incomes also allows their households to purchase products from other sectors or value-chains, thereby generating economy-wide spillovers. The table reports GDP growth and employment elasticities for the total economy and for the AFS only. The former is an indicator of agriculture-led development, whereas the latter is an indicator of agricultural transformation.

\footnotetext{
5 Income elasticities are estimated for rural and urban households using the 2010/11 household survey.
} 
Table 4.3. Economywide Growth and Employment Linkages for Ethiopia, 2016-2020

\begin{tabular}{|c|c|c|c|c|c|c|c|c|}
\hline \multirow{3}{*}{$\begin{array}{l}\begin{array}{c}\text { Targeted sector within } \\
\text { agriculture }\end{array} \\
\text { Maize }\end{array}$} & \multicolumn{4}{|c|}{ GDP growth elasticity } & \multicolumn{4}{|c|}{ Employment elasticity } \\
\hline & \multicolumn{2}{|c|}{ Total } & \multicolumn{2}{|c|}{$\begin{array}{l}\text { Agriculture-food } \\
\text { system (AFS) only }\end{array}$} & \multicolumn{2}{|c|}{ Total } & \multicolumn{2}{|c|}{$\begin{array}{l}\text { Agriculture-food } \\
\text { system (AFS) only }\end{array}$} \\
\hline & 0.44 & (4) & 0.87 & (5) & 0.11 & (4) & 0.10 & (4) \\
\hline Sorghum/millet & 0.42 & (6) & 0.87 & (6) & 0.05 & (5) & 0.05 & (5) \\
\hline Wheat/barley & 0.37 & (11) & 0.85 & $(10)$ & -0.21 & (11) & -0.21 & (11) \\
\hline Teff & 0.43 & (5) & 0.85 & (9) & 0.15 & (3) & 0.14 & (3) \\
\hline Pulses & 0.39 & $(10)$ & 0.80 & $(11)$ & -0.12 & $(8)$ & -0.14 & $(7)$ \\
\hline Oilseeds & 0.11 & (15) & 0.52 & (15) & -1.51 & (14) & -1.48 & (14) \\
\hline Root crops & 0.35 & $(12)$ & 0.76 & $(13)$ & -0.17 & (9) & -0.15 & (10) \\
\hline Vegetables & 0.27 & (14) & 0.71 & (14) & -0.95 & (13) & -1.01 & (13) \\
\hline Fruits/tree crops & 0.41 & (8) & 0.86 & (8) & 0.02 & (6) & 0.01 & (6) \\
\hline Coffee & 0.54 & (3) & 0.94 & $(4)$ & 0.91 & (1) & 1.00 & (1) \\
\hline Tobacco/cotton/tea & 0.56 & $(2)$ & 1.16 & $(2)$ & 0.35 & (2) & 0.36 & (2) \\
\hline Milk/dairy & 0.40 & (9) & 0.94 & (3) & -0.27 & $(12)$ & -0.33 & $(12)$ \\
\hline Cattle & 0.62 & (1) & 1.59 & (1) & -2.58 & (15) & -3.04 & (15) \\
\hline Poultry & 0.42 & (7) & 0.86 & (7) & -0.10 & (7) & -0.15 & (8) \\
\hline Goats/sheep/camels & 0.34 & (13) & 0.78 & $(12)$ & -0.18 & $(10)$ & -0.15 & (9) \\
\hline
\end{tabular}

Source: RIAPA CGE Model and SAM.

Notes: AFS is agriculture-food system; total is the whole economy. GDP (employment) elasticity is the percentage increase in total or agriculture-food system GDP (employment) given a one percent increase in agricultural GDP.

Sectoral rank in parentheses.

Agricultural activities with downstream processing generate larger growth multiplier effects within the AFS. Cattle and tobacco, for example, supply downstream meat processing and tobacco-curing activities. Cattle's AFS growth elasticity of 1.59 implies that a one percent increase in agricultural GDP driven by cattle productivity increases AFS GDP by 1.59 percent. However, livestock and meat processing tend to be more capital-intensive activities, at least compared to other value-chains, and so cattle is one of the least effective value-chains at creating jobs outside of agriculture. Tobacco/cotton/tea has an AFS employment elasticity of 0.36 , implying that a one percent increase in agricultural GDP driven by productivity gains for these crops causes AFS employment to increase by 0.36 percent. Overall, the value-chains with the largest AFS growth effects are cattle, tobacco/cotton/tea, and milk/dairy, whereas the largest AFS employment elasticities are for coffee, tobacco/cotton/tea, and teff. Differences between the rankings of growth and employment effects indicates a trade-off between the absolute number of jobs created and the "quality" or labor productivity of these jobs. Expanding cattle production creates few jobs, but GDP per worker in these jobs is high.

Table 4.3 also shows how growth effects may differ when considering the whole economy, rather than just the AFS. Teff, for example, is one of the least effective value-chains at generating AFS growth, but it is more effective at generating economy-wide growth. This is because there is relatively little downstream processing of teff within the AFS, but it is an important income source for many farmers. Raising these farmers' incomes generates demand for non-AFS products. Teff also directly benefits consumers, and not just teff farmers. For these reasons, teff's economy-wide growth multiplier effect is larger, relative to other value-chains, than its AFS growth effect. That being said, the Ethiopian agrarian economy is dominated by the AFS, implying that whatever is beneficial for the AFS tends to also be beneficial for the broader economy. 


\section{FINAL ASSESSMENT}

No single value-chain is most effective at achieving all policy objectives. Figure 5.1 shows the ten highest ranked value-chains across three selected outcomes: (1) reducing the rural poverty headcount rate; (2) diversifying poor rural households' diets; and (3) promoting AFS GDP growth. Four products are in the topten on all three indicators: coffee, fruits/tree crops, pulses, and tobacco/cotton/tea. Sorghum/millet, teff, and wheat/barley are effective at reducing poverty and generating growth, but they narrow diets, rather than diversify them. Vegetables and oilseeds diversify diets and reduce rural poverty, but have more limited growth effects. Cattle, milk/dairy, and poultry promote growth and diversify diets, but are less effective at raising poor households' consumption either directly as a supplier of food or indirectly as a source of income. Of these value-chains, those with one of the ten strongest employment effects are marked with an asterisk.

Figure 5.1. Value-chains in Ethiopia with Strong Poverty, Nutrition, and Growth Effects

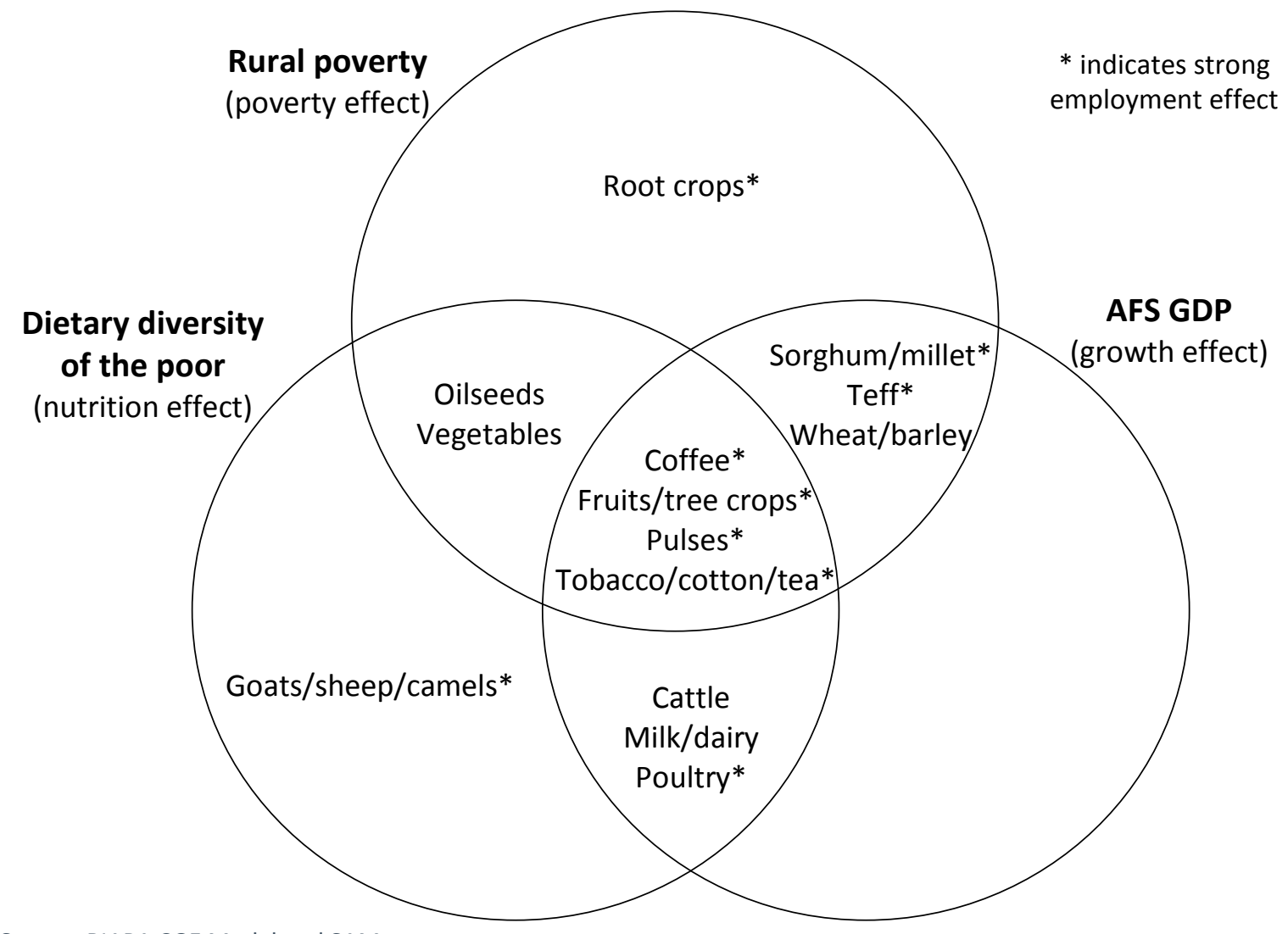

Source: RIAPA CGE Model and SAM.

Notes: Poverty effect uses rural headcount PGE (column 2 in Table 4.1); nutrition effect uses poor rural households' DDGE (column 3 in Table 4.2); and growth and employment effects are for AFS only (columns 2 and 4 in Table 4.3).

A portfolio of value-chains is needed to achieve all policy objectives. Figure 5.1 does not convey valuechains' relative strengths across outcome indicators. For example, vegetables are far more effective at diversifying diets than most other value-chains (see Table 4.3). Such a strong nutrition effect might outweigh concerns about vegetables' weaker growth effect. One approach to evaluating these kinds of trade-offs is to combine growth, poverty, and nutrition outcomes into a weighted or composite indicator. Table 5.1 reports the final prioritization of value-chains using different weighting schemes. The first column assigns equal weights across outcomes, whereas the other columns give greater weight to each indicator, i.e., attributing half of the weight to one outcome and a quarter to the other two, thus creating a bias towards specific outcomes. The final analysis suggests that vegetables and fruits/tree crops should be 
considered "priority" value-chains, since these are highly-ranked irrespective of how outcomes are weighted. Other value-chains that rank highly on multiple outcomes include oilseeds, tobacco/cotton/tea, and milk/dairy.

Table 5.1. Final Rankings of Value-chains in Ethiopia under Different Weighting Schemes

\begin{tabular}{rllll}
\hline Rank & \multicolumn{1}{c}{ Equal weights } & \multicolumn{1}{c}{ Poverty Bias } & \multicolumn{1}{c}{ Nutrition Bias } & \multicolumn{1}{c}{ Growth Bias } \\
\hline 1 & Oilseeds & Oilseeds & Vegetables & Cattle \\
2 & Fruits/tree crops & Vegetables & Fruits/tree crops & Tobacco/cotton/tea \\
3 & Vegetables & Fruits/tree crops & Oilseeds & Fruits/tree crops \\
4 & Tobacco/cotton/tea & Tobacco/cotton/tea & Milk/dairy & Milk/dairy \\
5 & Cattle & Pulses & Pulses & Vegetables \\
\hline 6 & Milk/dairy & Milk/dairy & Tobacco/cotton/tea & Coffee \\
7 & Pulses & Coffee & Cattle & Pulses \\
8 & Coffee & Root crops & Coffee & Oilseeds \\
9 & Poultry & Cattle & Poultry & Poultry \\
10 & Goats/sheep/camels & Sorghum/millet & Goats/sheep/camels & Sorghum/millet \\
\hline
\end{tabular}

Source: RIAPA CGE Model and SAM.

Note: Rankings based on weighted sum of outcome indicators. Equal weighting is one-third each; biased weighting favors one indicator (one-half) at the expense of others (one-quarter each).

In conclusion, Ethiopia's dominant agricultural activities - cereals and coffee - contribute positively to national pro-poor growth. Cereals, for example, are still important for achieving the first-phase CAADP targets of accelerating agriculture-led growth and poverty reduction. However, the analysis presented here suggests that a more balanced portfolio of value-chains would not only enhance agriculture's future contribution to poverty reduction and economic growth, but also promote faster rural transformation and dietary diversification, both of which are needed to create job opportunities and improve nutrition outcomes over the longer-term. Nutrition and job creation are additional objectives for CAADP's second phase. This brief has identified new priority value-chains based on the potential contributions to national development. Further analysis of these value-chains' growth and market potential is needed.

\section{APPENDIX}

Table A1. Composition of Value-chain Product Categories

\begin{tabular}{ll}
\hline \multicolumn{1}{c}{ Category } & \multicolumn{1}{c}{ Detailed agricultural products in the product category or value-chain } \\
\hline Maize & Maize \\
$\begin{array}{l}\text { Sorghum/millet } \\
\text { Wheat/barley }\end{array}$ & Sorghum; millet \\
Teff & Wheat; barley \\
Pulses & Teff \\
Oilseeds & Beans; pigeon peas; chick peas; cow peas; dry peas; dry lentils; other pulses \\
Root crops & Soybeans; sunflower seed; groundnuts \\
Vegetables & Potatoes \\
Fruits/tree crops & Tomatoes; cabbages and other brassicas; onions; other vegetables \\
Coffee & Plantains; bananas; mangoes; guavas; other fresh, citrus and tropical fruits; tree nuts \\
Tobacco/cotton/tea & Coffee \\
Milk/dairy & Tobacco; cotton; tea \\
Cattle & Milk; dairy \\
Poultry & Cattle \\
Goats/sheep/camels & Poultry; eggs \\
Other agriculture & Sheep; goats; camels; other livestock products \\
\hline
\end{tabular}


Rui Benfica is Lead Economist, Research and Impact Assessment Division, Strategy and Knowledge Department, International Fund for Agricultural Development (IFAD) and James Thurlow is a Senior Research Fellow in the Development Strategy and Governance Division of IFPRI, based in Washington DC.

\section{About ESSP}

The Ethiopia Strategy Support Program is an initiative to strengthen evidence-based policymaking in Ethiopia in the areas of rural and agricultural development. Facilitated by the International Food Policy Research Institute (IFPRI), ESSP works closely with the government of Ethiopia, the Ethiopian Development Research Institute (EDRI), and other development partners to provide information relevant for the design and implementation of Ethiopia's agricultural and rural development strategies. For more information, see http://www.ifpri.org/book-757/ourwork/program/ethiopia-strategy-support-program;

http://essp.ifpri.info/; or http://www.edri-eth.org/.

The ESSP Working Papers contain preliminary material and research results from IFPRI and/or its partners in Ethiopia. The papers are not subject to a formal peer review. They are circulated to stimulate discussion and critical comment.

INTERNATIONAL FOOD POLICY RESEARCH INSTITUTE

1201 Eye Street, NW | Washington, DC 20005-3915 USA

$\mathrm{T}:+1.202 .862 .5600 \mid \mathrm{F}:+1.202 .862 .5606$

Email: ifpri@cgiar.org | www.ifpri.org

IFPRI-ESSP ADDIS ABABA

P.O. Box 5689, Addis Ababa, Ethiopia

$\mathrm{T}:+251.11 .617 .2000 \mid \mathrm{F}:+251.11 .646 .2318$

mahlet.mekuria@cgiar.org | http://essp.ifpri.info
ETHIOPIAN DEVELOPMENT RESEARCH INSTITUTE

P.O. Box 2479, Addis Ababa, Ethiopia

T: +251.11.550.6066; +251.11.553.8633 | F: +251.11.550.5588

info@edri-eth.org | www.edri-eth.org

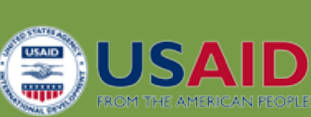

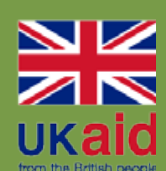

The Ethiopia Strategy Support Program (ESSP) is managed by the International Food Policy Research Institute (IFPRI) and is financially supported by the United States Agency for International Development (USAID), the Department for International Development (DFID) of the government of the United Kingdom, and the European Union. The research presented here was conducted as part of the CGIAR Research Program on Policies, Institutions, and Markets (PIM), which is led by IFPRI. This publication has been prepared as an output of ESSP and has not been independently peer reviewed. Any opinions expressed here belong to the author(s) and do not necessarily reflect those of IFPRI, the Ethiopian Development Research Institute, USAID, DFID, the European Union, PIM, or CGIAR.

Copyright @ 2017, Remains with the author(s). All rights reserved. 